\title{
Biologically Inspired Self-adaptive Multi-path Routing In Overlay Networks
}

\section{オーバレイネットワークにおける生態系パラダ イムに基づく自己適応型複数経路ルーティング}

\section{Kenji Leibnitz, Naoki Wakamiya, and Masayuki Murata}

\section{ネットワーク経路選択におけるる最適解発見のためにランダム性を利用する}

生物システムに見られる機構は，環境にお ける変化に対して一般に十分頑強で適応して いる。したがって，自然界に見られる挙動を 模倣した多くの手法がコンピュータサイエン スにおいて実装されてきた。これらのいくつ かの手法（人工ニューラルネットワーク，シ ミュレーテッドアニーリング，遺伝的アルゴ リズム）は，不完全または曖昧な入力データ の問題に対する最適化手法として特によく機 能する.

生態系パラダイムに基づく新しい情報技術 の研究を促進させるために，“ネットワーク 共生環境を築く情報技術の創出” という題目 のプロジェクトが大阪大学において 2002 年 に始まった。情報科学, バイオインフォマテ イクス, そして応用数学分野からの研究者と の緊密で学際的な協力は，様々な生体の抽象 行動モデルの発見, および通信ネットワーク, 特にピアツーピア (P2P) ネットワーク，モ バイルアドホックネットワーク (MANETs), そしてセンサネットワークに対する新しい制 御手法へのモデルの適用を可能にした.

自然界では，生体は常に変動する環境に直 面する，そのような変わりゆく状況への適応 は生体の生存にとり本質である。しかし，生 息地の高次元性により，それぞれの環境変化 は個々の生体の生存期間には滅多に繰り返さ れない。結果として，適応規則の構築が常に 可能というわけではない。なぜならば学習と
進化プロセスは生体が適応しようとする事象 が何度も発生することを必要とするからであ る. 入力パターンと望まれる目標值が存在す れば，パターン学習（例えば人工ニューラル ネットワークによく利用される）だけは可能 となる. 利用可能な入力パターンまたは望ま れる目標值が無いとき, 新しい状況への適応 はより自己組織化された方法で行われる。例 えば，遺伝子ネットワークにある細胞は，利 用可能な栄養素の量により，ある状態から他 の状態へ移ることができる[6]. これらの手法 は全体性能の観点からは必ずしも最適ではな くてもよく, 頑強さと持続可能性が主な長所 である。これは予測不能で変動する環境下で の生存にとって非常に重要である.

自己適応性は情報技術の多くの分野，異種 ネットワークの相互作用を考えると特に遠隔 通信において重要な問題である. 本記事では, データパケットの送信をそれぞれの経路の計 測基準の変化に適応させることによって，才 一バレイネットワーク上での複数経路ルーテ イングの問題[3]を解決する手法を提案する. 典型的にオーバレイルーティングに採用され ている End-to-End の経路選択のスキームは とても自己的な性質を持っている. システム 全体の性能および安定性とは関係なく，最高 性能を提供する経路を領欲に選択するからで ある。ゲーム理論のアプローチを利用する自 己的なルーティングは幾つかの文献[9]によ 


\section{自己適応性は, 異種ネットワークの相互作用を考える場合, IT の多くの分野，特に通信において重要な問題である}

って詳細に調べてられてきた. ルーティング の最適化は，例えば最良なネットワーク構成 を見つけるために線形計画法を用いるなど， 全体的なネットワークの観点でしばしば行わ れるが，ここで提案される解決手法では，ノ ードがリンクの計測から得ることができる限 られた狭い範囲の情報だけに着目する。

Seshadri と Ktz[10]の提案によると, 自己的 な度合いに制約を課すことによってシステム の全体的な安定性は改善する。

利用者最適もしくは自己的なルーティング は，利用者が一方的にルートを変化させよう としないという Wardrop 均衡を実現する.

Xie ら[12]は利用者 最適およびネット ワーク最適ルーテ イングを考慮に入 れたルーティング スキームを考案し た. 前者においては Wardrop 均衡に収 束し, 後者は最小遅 延に収束する。 Su と de Veciana[11] は, 動的な複数経路

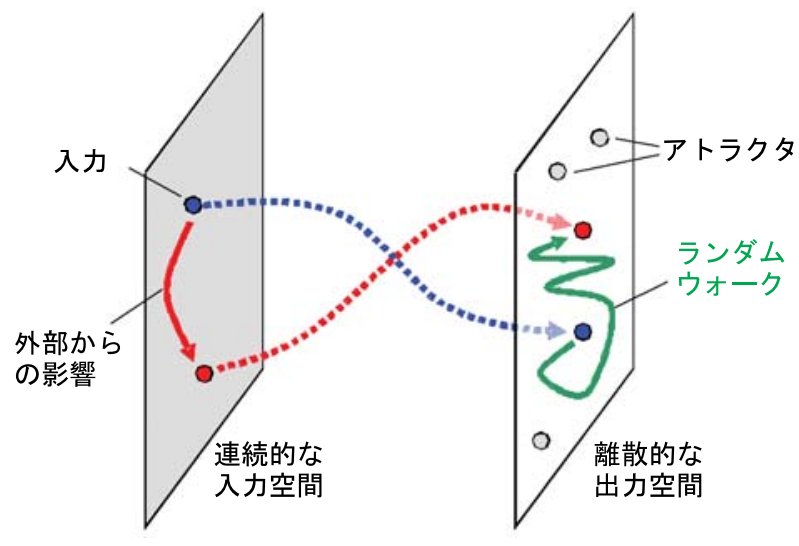

法は，蟻の集団を模倣するモバイルエージェ ントを利用した AntNet[4]である。この手法 はそれぞれの中間ノードにおいて蟻をルート 探索に送り出し，またルーティングテーブル の更新に蟻を送り返して動作する。その後,

トラフィックはある確率で特定の経路にルー ティングされる.ただし，ここで考えている 問題は，すでに決められた経路の適応的な選 択に焦点を置いているという点でいままでの アプローチとは異なっている.

\section{アトラクタ選択による適応応答}

アトラクタ選択による適応応答(ARAS)の 生物学的モデルは, 環境から DNA への 信号伝達のための 分子機構が利用で きない状態で, 利用 可能な栄養素の量 の変化に対し, どの ように E. coli 細胞 が適応するかをモ デル化するために， 柏木ら[6]によって 提案された.この機 構の注目すべき特 いて最適なリンク数を導く複数経路ルーティ ングのための解析的モデルを提案している. 彼らは最も負荷の低いリンクヘトラフィック をルーティングするための方針を指定し，集 中的なトラフィックのある高速ネットワーク においてこの方針が特に適していることを示 している.もう一つの適応的複数経路ルーテ イングアルゴリズムは Gojmerac ら[5]によっ て提案されている。そのアルゴリズムは単純 なデータ構造を用い, 下位層のルーティング プロトコルとは独立している。これは局所的 な信号伝達と負荷平衡を利用することによっ てなされ，信号伝達のオーバヘッドを削減す る結果になっている.

ルーティングに非常に適しているもう一つ のよく知られた生態系パラダイムに基づく手
図 1.アトラクタ選 択による適応応答 の原理

徵は，ノイズに対し 非常に寛容で，ノイ ズによって促進しさ えすることである。

基本的に ARAS は以下のように動作する. すべての動的システムのように，システムの 動作は一組の微分方程式によって特徴づけら れ，根底にある方法が非常に数学的なので式 （1）で示される単純化された方程式で簡単に 記述できる。

$$
\frac{d m_{i}}{d t}=f\left(m_{1}, \ldots, m_{M}\right) \times g(\alpha)+\eta_{i} \quad i=1, \ldots, M
$$

システム状態は $m_{i}$ の值によって与えられ, そ の動作は二つの関数 $f$ および $g$ に影響を受け る. システムが進化するとき, 式（1）におけ 
る関数 $f$ と $g$ の積によって定義される平衡点 一収束する. また，平衡点は安定したアトラ クタであり，その一つへ自動的にシステム状 態が引きつけられるように構成される.

さらに, $M$ 個の微分方程式はそれぞれ遺伝 子モデルに見られるノイズに対応するランダ ム要素 $\eta_{i}$ を持つ.このランダムノイズはシス テム状態を定期的に動作させる。しかし，一 旦一つの平衡点一収束すると, アトラクタが 安定している限りそこに在り続ける. 我々の アプローチでは, 環境から影響を及ぼす要素 (栄養素) と考えられている要素に対してどの 程度十分に現在のシ ステム状態が対応し ているかを示す活性 度 $\alpha$ によって適切な アトラクタの選択制 御を行う. 現在のシス
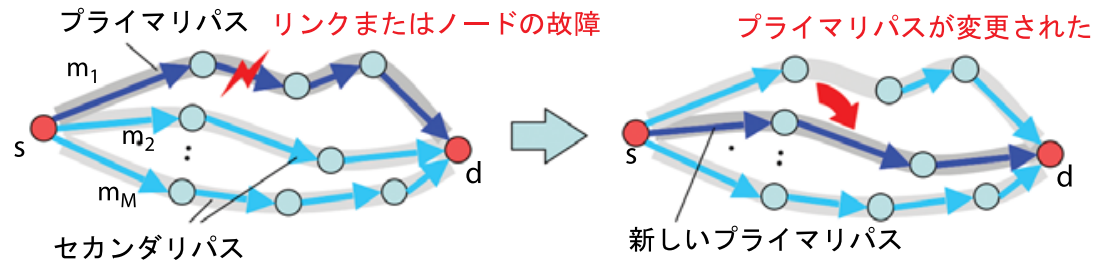

テム状態が環境に相 応しくなければ, 活性 度はアトラクタを不 安定にさせることに

図 2.プライマリパ スの故障に対する 反応

よって微分方程式に直接影響を及ぼす。その ような場合, 式 (1) の $g(\alpha)$ が 0 になり, 右 辺はランダムノイズの項が支配的となり，実 質的にランダムウォークとなる. このランダ ムサーチにおいて，より良い解に達するとす ぐに活性度の值は増加し, ランダムノイズの 影響は減少する (図 1 を参照).

これがどのように動作するかさらに説明す るために, システム状態（金属球）が引きつ けられる電磁石（アトラクタ）との類似を考 えることができる，それぞれの磁石が独立に 活性化されるが，いつでも一つの磁石だけが 活性状態になる，活性の動作は，活性化され ている磁石が現在の環境を反映するかを決定 することに対応する．このようにして，アト ラクタ選択の抽象公式化では, 図 1 のように 連続的な入力空間の離散的な出力空間へのマ ッピングとしてみることができる.

\section{ARAS による複数経路ルーティング}

ここで提案している手法は本来パケット交 換ネットワークのルーティング構造に応用可 能である。しかし，現在インターネットに使 用されている IP ルーティングを強化しよう とすることは非現実的である. その代わりと
して, より現実的な場面は, 例えば Resilent Overlay Network (RON) [2] アーキテクチ ヤのような IP ネットワーク上のオーバレイ ルーティングを考えることである. Andersen ら [2]は, 経路遮断へのより早い反応のため に, RON が従来の Border Gateway Protocol (BGP) ルーティングに比べ損失割合とスルー プットを改善することができることを示して いる.

アトラクタ選択の考え方をオーバレイルー ティングの問題へ応用させる方法を以下の通 りである。まず，それぞれのノードがトポロ
ジーの正確な知識を持たず，す心゙ての情報を リンクの計測によって取得すると仮定する. オーバレイネットワーク上で $M$ 個の伝送路 を持つある送信元と送信先の組に対し，一つ の経路が現在の環境に依存してプライマリパ スとして選択される。この経路が最も良い計 測基準（最小遅延または高帯域幅）を備えた 経路であり, トラフィックの大半がこの経路 上で伝送される. 他の経路はセカンダリパス となり, パケットが低確率で伝送される. 状 況が変化し, 現在のプライマリパスがもはや 最良の選択ではなくなると, アトラクタ選択 手法により新しいプライマリパスを決定す る. 我々のモデルでは, 測定された入力計測 基準を活性度の值にマッピングすることによ って現在のシステム状態を評価する。

望まれる動作は図 2 に示されている. 送信 元 $\mathrm{s}$ と送信先 $\mathrm{d}$ の間に $M$ 個の経路があり, そ れらのうち一つがプライマリパスである。プ ライマリパス上でリンク遮断もしくはノード 故障が起きれば，プライマリパスは自動的に 最良のセカンダリパスに切り替わる. 経路の 切り替えはリンク遮断のような極端な状況だ けではなく, ネットワーク負荷の変化によっ てセカンダリパスの一つがプライマリパスよ りも適切になったときにも起こるべきであ る、ルーティングアルゴリズムの基本的な動 作はルートセットアップとルートメンテナン スの二つのフェーズから成っている. 


\section{ルートセットアップフェーズ}

ルートセットアップフェーズでは, Adhoc

On-Demand Distance Vector (AODV) ルー ティング[8]に見られるような分散型の手法 を利用する. 送信先への新たなルートの要求 が送信元ノードへ到着したとき, ルート要求 メッセージをネットワークにブロードキャス トする．隣接するノードがそのようなメッセ ージを受信し，送信先へのルートを持ってい なければパケットを隣接ノードへブロードキ ヤストし続ける. しかし, すでに処理された ルート要求メッセージを受信した時は, その メッセージを廃棄する。ルート要求メッセー ジが送信先ノードに到着する, またはテーブ ルに送信先へのルートをすでに保持している ノードへ到着した場合には，ルートを要求し ている送信元ノードヘルート反応メッセージ を返す. 最初のルート反応メッセージが送信 元へ到着すると, この送 信元ノードは送信先ノ ードへのルートを知り, パケット送信のための このルートを使い始め ることができる.このよ うに，M 個までのルー トが徐々に収集され，こ れら $M$ 個の経路でルー トメンテナンスフェー ズが続けられる. 共通の リンクやノードを共有 しない素なルートを確 立するための他の手法 も同様に利用寸ること ができる.

不明なノードへの送信要求が送信元へ到着 したときにルートセットアップフェーズが開 始される. その後, ルートメンテナンスフェ 一ズが始まる．本手法では時間の殆どがこの フェーズで動作する.しかし, 経路が消失し て経路の最小数の閾值に到達すれば，ルート セットアップフェーズに再度入る.

\section{ルートメンテナンスフェーズ}

一旦送信元から送信先への最初の経路が確 立されると, ルートメンテナンスフェーズに 入る.このフェーズではパケットを送信する
ための経路を選択するためにアトラクタ選択 モデルが使用される。このアトラクタ選択は それぞれの経路に関連する計測基準值によっ て成される. 計測基準の一例はパケットの往 復時間を計測して得られる送信遅延である。 送信遅延は，インライン計測（一般に能動的 な遅延計測はネットワークのオーバヘッドを 極度に増加させる）によってキャプチャする ことができる。

オーバレイネットワークのルーティングに おける主な問題は, 最良の経路がしばしば全 く自己的な方法で選択され, 結果としてシス テム全体の性能が考慮されないことである. これはネットワーク負荷の望まれぬ摇らぎや 不安定さを引き起こすかもしれない。

Seshadri と Katz[10]はシステム全域の安定 性と性能を改善するためにこの食欲な動作に 対し三つの制限を課すことを提案している. その三つの制限は, ルート選択におけるラン ダム化, 履歴の閾值によ るルート変化, そしてル 一ト変化期間の増加で ある. 経路選択のランダ ム化はそれぞれの経路 選択に対し確率を用い ることによって我々の モデルに容易に加える ことができる.さらに， 経路計測基準の変化の 活性度へのマッピング を行うときに履歴の閾 值が考慮される。これは 活性のダイナミックス を記述する微分方程式 図 3. 提案モデ に含まれている. 他のラ ルによる遷移 ンダム化されたアプロー 確率 チとの比較とともに, 詳 細な方程式は[7]に書かれ

ている.

非常に複雑な数学が関与しているにもかか わらず，我々のアプローチの実装は極めて単 純である. 微分方程式は, 確率的微分方程式 のためのオイラー・丸山法によって数值的に 反復計算される. 結果は経路選択に用いられ る確率を生成するために正規化される。 あと は閾值レベルと比較して, 活性経路を追加, 削除することによって活性経路を管理するこ 
とである．それ以外には，どんな規則も使用 されず，システムは完全に自主的に動作する ことができる.

$M=6$ の経路における経路の時間依存動作 の例は図 3 に与えられる.この場合, 他に記 述がなければすべての経路計測基準は等しい と仮定する. 結果として, 一つの経路に対す る特定の好みは存在せず，プライマリパスは ランダムに選択される，2,000 から 4,000の 時間ステップおよび 8,000 ステップ以降では 経路 1 (青線) が最良の計測基準を有してお り, それに応じて選択が実行されている. 我々 のアプローチの回復力を示すために 4,000 ス テップ以降では経路 2(緑線) が最良の計測 基準を有している。しかし，その経路は 6,000 ステップ以降機能しなくなり, 新たなプライ マリパスが即座に見つけられる. 図 3 はプラ イマリパスが機能しなくなった場合において も何ら困難なく我々が提案した手法が作用し 続けられることを示している. ランダムウォ ークの過程によって, 新たなプライマリパス を検索する場合において新たな解が見つかる 前に必要な遷移段階が時々存在していること も分かる. さらに, 反応遅延は計測とルート 更新のためのタイムウィンドウサイズに影響 を受けている.

\section{まとめ}

我々はアトラクタ選択による適応応答に基 づいた複数経路ルーティングのための新しい 生態系パラダイムに基づくアプローチを紹介 してきた. 提案手法は入力としての経路測定 基準を用いて自動的にそれぞれの経路に対す る適切なパケット送信確率を選択する. シス テムをアトラクタへ収束させることによって 明示的な規則の適用をすることなく経路選択 が行われる. 経路選択では最適解を見つける ためにランダム性を利用するため, ノイズの 影響に寛容であり変化する環境下において頑 強な動作をすることができる. 故障や一時的 な経路消失のための補正を容易に行うことが できる.もう一つの重要な利点は, 適切にタ ーゲットの活性レベルを設定することによっ て経路選択におけるランダム化の度合いを調 節できることである．提案手法は他のランダ ム性を用いた手法と比較して良好な性能と高 い柔軟性を示した（詳細は[7]を参照）。
この初めての研究が一組の送信元・送信先 ペアの動作を示す一方で, これは相互接続の 共生に対して容易に拡張できる。この場合, すべての相互フローあるいは活性レイヤの階 層構造を反映する活性度を考慮しなければな らない. しかし，この修正によって我々のア プローチはより分散しなくなると考えられ， 拡張性や性能一の影響をこれから調査しなけ ればならない。

基本的なアトラクタ選択手法の適用は複数 経路ルーティングの問題に制限されるもので はなく, 動的環境へ適応可能な一般最適化手 法としても考えることができる. 主な問題は 適切な入力パラメータの選択である. 我々の 実験では利用可能なパケットの帯域幅を考慮 したが，異なる測定基準の組合せを評価して システム状態を定義するときこの手法が実際 により正確になる.

\section{文献}

1. The 21st Century COE Program: New information technologies for building a networked symbiosis environment; www-nishio.ist.osaka-u.ac.jp/COE/english/.

2. Andersen, D., Balakrishnan, H., Kaashoek, F., and Morris, R. Resilient overlay networks. In Proceedings of the 18th ACM Symposium on Operating Systems Principles (SOSP), (Banff, Canada, Oct. 2001).

3. Andersen, D., Snoeren, A., and Balakrishnan, H. Best-path vs. multi-path overlay routing. In Proceedings of the Internet Measurement Conference (IMC 2003), (Miami, FL, Oct. 2003).

4. Di Caro, G. and Dorigo, M. AntNet: Distributed stigmergetic control for communication networks. J. Artificial Intelligence Research 9(1998), 317-365.

5. Gojmerac, I., Ziegler, T., Ricciato, F. and Reichl, P. Adaptive multi-path routing for dynamic traffic engineering. In Proceedings of IEEE GLOBECOM (San Francisco, CA, 2003).

6. Kashiwagi, A., Urabe, I., Kaneko, K. and Yomo, T. Adaptive response of a gene network to environmental changes by attractor selection. Submitted for publication in 
Proceedings of the National Academy of Sciences.

7. Leibnitz, K., Wakamiya, N., and Murata, M. Resilient multi-path routing based on a biological attractor selection scheme. In Proceedings of the 2nd International Workshop on Biologically Inspired Approaches to Advanced Information Technology (BioAdit 2006), (Osaka, Japan, Jan. 2006).

8. Perkins, C. and Royer, E. Ad hoc on-demand distance vector routing. In Proceedings of the 2nd IEEE Workshop on Mobile Computing System and Applications, (New Orleans, LA, Feb. 1999).

9. Qiu, L., Yang, Y., Zhang, Y., and Shenker, $\mathrm{S}$. On selfish routing in internet-like environments. In Proceedings of ACM SIGCOMM, (Karlsruhe, Germany, Aug. 2003).

10. Seshadri, M. and Katz, R. Dynamics of simultaneous overlay network routing. Tech. Rep. UCB//CSD-03-1291, University of California, Berkeley, CA, 2003.

11. Su, X. and de Veciana, G. Dynamic multipath routing: asymptotic approximation and simulations. In Proceedings of $A C M$ SIGMETRICS, (Cambridge, MA, June 2001).

12. Xie, H., Qiu, L., Yang, Y., and Zhang, Y. On self adaptive routing in dynamic environments - An evaluation and design using a simple, probabilistic scheme. In Proceedings of the International Conference on Network Protocols (ICNP 2004), (Berlin, Germany, Nov. 2004).

Kenji Leibnitz (leibnitz@ist.osaka-u. ac.jp）は，大阪大学大学院情報科学研究科 のポストドクトラルリサーチフェローであ る.

Naoki Wakamiya（wakamiya@ist. osaka-u.ac.jp）は，大阪大学大学院情報科 学研究科の助教授である.

Masayuki Murata (murata@ist.osaka -u.ac.jp）は，大阪大学大学院情報科学研究 科の教授である。

訳：今田貴之（筑波大学・システム情報工 学研究科) 